\author{
R. Strelchuk, Kharkiv, Ukraine
}

\title{
SURFACE ROUGHNESS MODELING DURING ELECTRIC DISCHARGE GRINDING WITH VARIABLE POLARITY OF ELECTRODES
}

\begin{abstract}
The article presents the probabilistic-statistical modeling of surface roughness in the process of electric discharge grinding with the variable polarity of electrodes. The correlation between electric modes of machining and indicators of the quality of the machined surface was established. A probabilistic-statistical model of part surface roughness formed during grinding is obtained, which establishes the correlation between high-altitude surface parameters and electrical machining modes. The developed model makes it possible to calculate the height parameters of the part roughness depending on the electrical modes of grinding. The height of microroughness is determined by the same machining conditions as the depth of erosion pits. It is possible to obtain low roughness if electrical machining modes are reduced.
\end{abstract}

Keywords: spatial position of erosion pits; statistical dimensions; roughness parameters; electrical modes.

Introduction. The process of electrical discharge grinding with the variable electrode polarity allows obtaining the required qualitative and quantitative parameters with a significant reduction in the specific consumption of the diamond wheel and the costs of various types of energy $[1,2]$. This is explained by the fact that changing in time on the polarity of the electrodes and the corresponding pulse repetition rate ensures stable conditions of the grinding process. By changing the pulses repetition rate, their duty ratio and power with a corresponding change in the polarity of electrodes, it is possible to regulate directly the process itself, up to an equilibrium state, ensuring equal manifestation of electrophysical and electrochemical (even at their insignificance) processes for both electrodes. The process of interaction between the cutting tool and the surface of the machined material under conditions of electrical discharge grinding with the variable polarity of electrodes has not been studied. In this connection, surface roughness modeling was carried out in the paper and the features and regularities of interaction between the cutting tool and the surface of the machined material were established.

Literature Review. The interaction of the diamond wheel with the surface of the machined material during electrical discharge grinding is a complex electrophysical system [3,4]. It is simultaneously a place of micro-cutting and the action of discharges in the interelectrode gap. When voltage is applied in this area, an electric current arises and passes through the current-conducting bridge circuits overlapping the interelectrode gap, the working fluid having some electric conductivity, and through the channel of the arising discharge during its action.

To determine the surface roughness, probabilistic-statistical modeling was 
performed. During electrical discharge grinding, the roughness of the machined surface is formed as a result of the formation of individual pits that overlap each other. Each pit can be represented as a spherical segment. Since the spherical segment has geometric symmetry relative to the vertical axis, the issue of pits formation was considered in a two-dimensional formulation. The section of the pit is a circular segment, the arc radius of which is equal to the radius of the spherical segment.

Research Methodology. Taking into account the stochastic nature of the pit formation process, the method of probabilistic-statistical modeling (Monte Carlo method) was used to determine the surface roughness, which involves the following. The individual vertex and cavity of irregularities of the machined surface are formed by superimposing two repeatedly modeled pits (Fig. 1). For this purpose, the values of geometrical parameters of the pits $\left(d_{l}\right.$ and $\left.h_{l}\right)$ and the values of parameters of the intersection of the pits were played out with a random number generator according to the law of normal distribution and their marginal values were obtained.

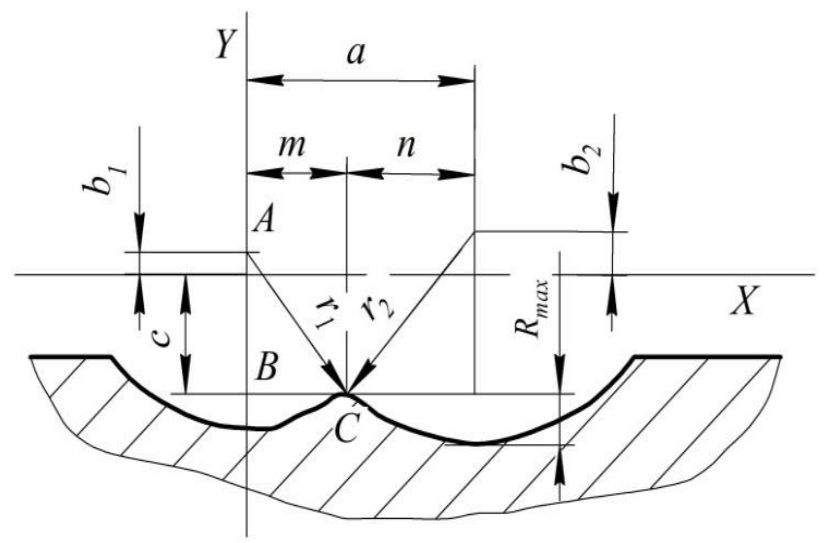

Figure 1 - Scheme for calculating the roughness of the machined surface

The roughness of the machined surface $R_{\max }$ was calculated by the formula:

$$
R_{\max }=r_{\max }-b_{\max }-c_{\min }
$$

where $r_{\max }$ is the largest value of the arc radius; $b_{\max }$ is the largest value of the distance between the $X$ axis and the center of the larger arc of all realizations; $c_{\min }$ is the smallest value of the distance between the intersection point of the arcs and the $X$ axis of all realizations. 
Let us define the parameter $c$ at the intersection of two pits. The distance along the $X$ axis between the centers of two intersecting arcs $a$ is determined from the range from $a_{\min }$ to $a_{\max }$ and can be found as

$$
a=m+n,
$$

where $m$ is the distance between the center of the first arc and the intersection point of the $\operatorname{arcs} ; n$ is the distance between the center of the second arc and the intersection point of the arcs.

From triangles $A B C$ and $A_{l} B_{l} C$ we have:

$$
\begin{aligned}
& r_{1}^{2}=m^{2}+\left(b_{1}+c\right)^{2} \\
& r_{2}^{2}=n^{2}+\left(b_{2}+c\right)^{2}
\end{aligned}
$$

where $r_{1}, r_{2}$ are the radii of two intersecting arcs; $b_{1}, b_{2}$ are the distances between the $X$ axis and the centers of two arcs.

Solving equations (3) and (4) we obtain:

$$
\begin{aligned}
& m=\sqrt{r_{1}^{2}-\left(b_{1}+c\right)^{2}}, \\
& n=\sqrt{r_{2}^{2}-\left(b_{2}+c\right)^{2}} .
\end{aligned}
$$

Summing $m$ and $n$, we have:

$$
m+n=\sqrt{r_{1}^{2}-\left(b_{1}+c\right)^{2}}+\sqrt{r_{2}^{2}-\left(b_{2}+c\right)^{2}} .
$$

Given (2), expression (5) can be reduced to the form:

$$
\sqrt{r_{1}^{2}-\left(b_{1}+c\right)^{2}}+\sqrt{r_{2}^{2}-\left(b_{2}+c\right)^{2}}-a=0 .
$$

The parameter $c$ cannot be found explicitly from the obtained expression, so a numerical method is used to solve it.

It is known [5] that the relation between the depth and the diameter of an erosion pit has the following form:

$$
\frac{d_{m}}{h_{m}}=3 \ldots 4 .
$$

From the $A B C$ triangle (Fig. 2) we have

On the other hand

$$
r^{2}=\left(\frac{d_{m}}{2}\right)^{2}+k^{2} .
$$

$$
r=k+h_{n} .
$$


Hence

$$
k=r-h_{n}
$$

Given (8) and (6), expression (7) can be represented as

$$
5 h_{\pi}^{2}-2 h_{\pi} r=0 .
$$

Solving this equation, we find the dependence of the arc radius $r$ on the depth of the pit $h_{l}$ :

$$
r=2.5 h_{\pi}
$$

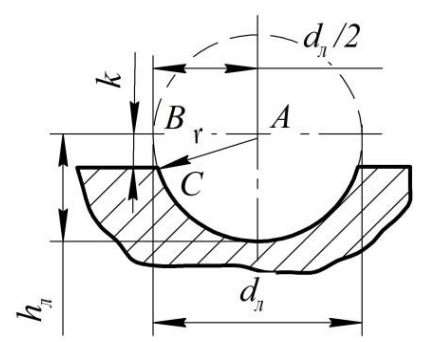

Figure 2 - Scheme for calculating the arc radius of the electrical discharge pit

Let us determine the maximum distance $a_{\max }$ on the $X$ axis between the centers of the two intersecting arcs. In this case, the intersection point is on the outer machined surface (Fig. 3).

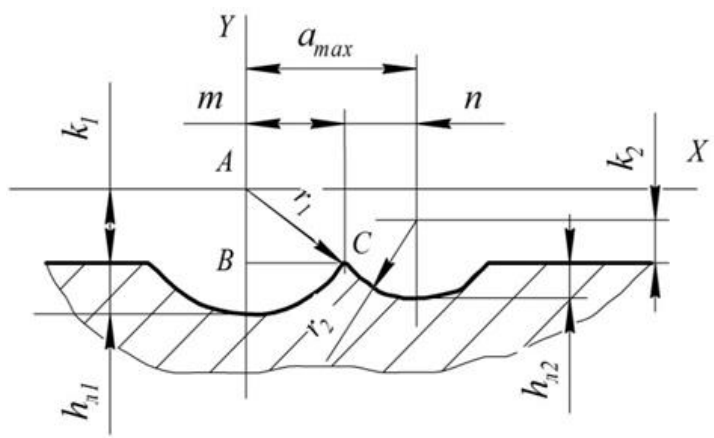

Figure 3 - Scheme for determining the $a_{\max }$ parameter 
From equation (9) we express $h_{l}$ as

Substituting (10) into (8), we obtain:

$$
h_{\mathrm{n}}=0.4 r \text {. }
$$

$$
k=0.6 r .
$$

The $a_{\max }$ parameter is defined as

From the triangle $A B C$ we have:

$$
a_{\max }=m+n
$$

Hence

$$
r_{1}=m^{2}+k_{1}^{2} \text {. }
$$

$$
m=\sqrt{r_{1}^{2}-k_{1}^{2}} .
$$

Given relation (11), we obtain:

$$
m=0.8 r_{1} \text {. }
$$

Similarly:

$$
n=0.8 r_{2} \text {. }
$$

Substituting dependences (13) and (14) into equation (12), we obtain the final expression for determining $a_{\max }$ :

$$
a_{\max }=0.8\left(r_{1}+r_{2}\right) .
$$

Let us determine the minimum distance $a_{\min }$ on the $X$ axis between the centers of the two intersecting arcs. The point of intersection of the two arcs is on the inner surface of the machined material (Fig. 4).

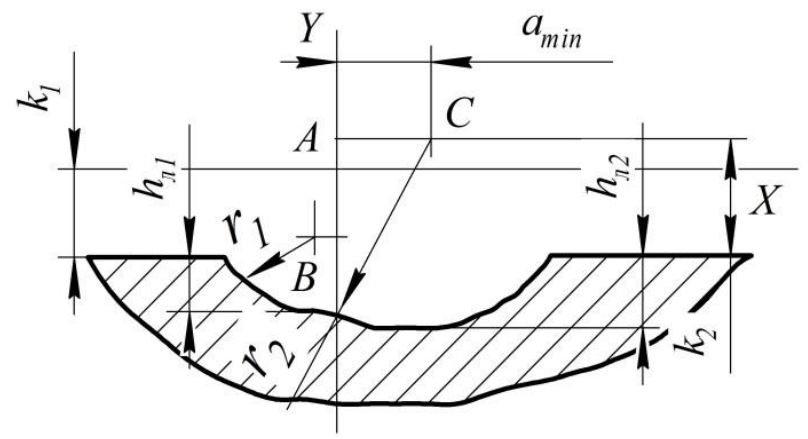

Figure 4 - Scheme for determining the parameter $a_{\min }$. 
From the triangle $A B C$ we have:

$$
r_{2}^{2}=\left(h_{\pi 1}+k_{2}\right)^{2}+a_{\min }^{2}
$$

Given relations (10) and (11), we can write:

$$
r_{2}^{2}=0.16 r_{1}^{2}+0.48 r_{1} r_{2}+0.36 r_{2}^{2}+a_{\min }^{2}
$$

Solving this equation concerning $a_{\min }$ we obtain:

$$
a_{\min }=\sqrt{0.64 r_{2}^{2}-0.48 r_{1} r_{2}-0.16 r_{1}^{2}} .
$$

Let us assume that the center of the arc with minimum radius $r_{\min }$ is on the $X$ axis. Then, considering relation (6), the center of the arc with a larger radius will be higher on the $Y$ axis. On this basis, let us define parameter $b$ (Fig. 5).

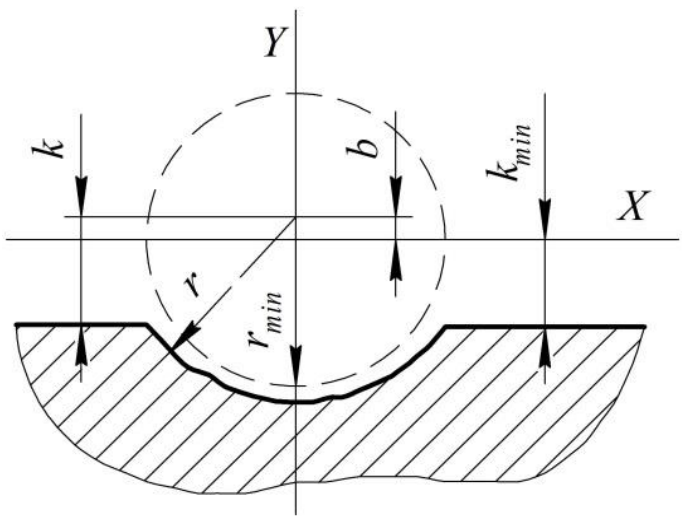

Figure 5 - Scheme for determining the parameter $b$

Let us express $b$ through $k$ and $k_{\min }$, and given (11), we obtain:

$$
b=0.6\left(r-r_{\min }\right) .
$$

Results. Following the above-specified method, we have developed a calculation algorithm, the scheme of which is shown in Fig. 6. The calculation sequence is as follows. The values of electrical modes are set: voltage $U$, current rate $I$, pulse duration $T$. Then, the expectation of the erosion pit depth $h_{л}$ and the standard deviation are calculated. Then the values of $r_{\max }, r_{\min }$, and $b_{\max }$ are 
determined. After that, with the help of a random number generator, the parameters $h_{\pi l}, h_{\pi 2}, r_{1}, r_{2}, a, b_{1}, b_{1}$, and $c$ are played out according to the normal distribution law. The number of repetitions is taken as equal to 1,000 . Then the value of $c_{\min }$ is determined. After that, surface roughness parameters are calculated: $R_{\max }, R_{a}, R_{z}$.
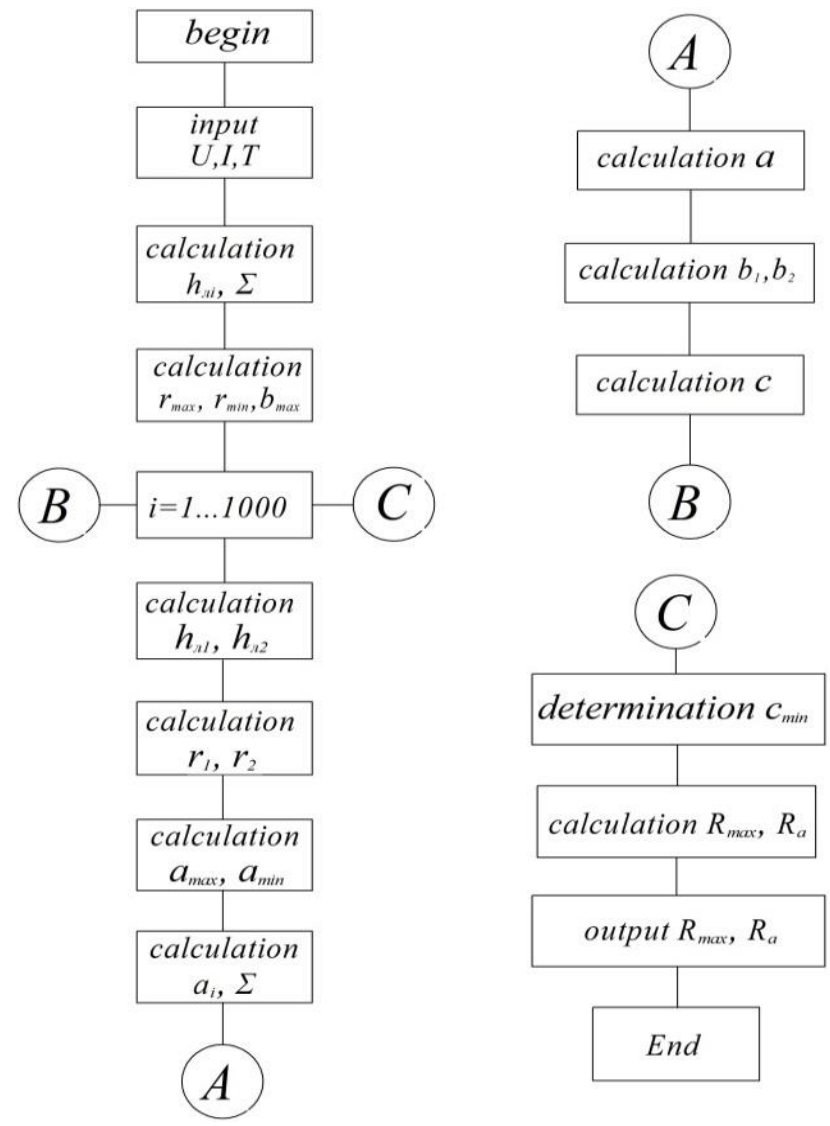

Figure 6 - Scheme of the algorithm for calculating the roughness parameters of the machined surface.

Conclusions. The developed model, considering the spatial position of erosion pits, their statistical dimensions, allows calculating the roughness parameters, which, eventually, make it possible to predict the durability of the formed part. The process of electrical discharge grinding with the variable polarity 
of electrodes allows reducing roughness parameters, which leads to an increase in durability and reliability of the machined part operation.

References: 1. Strelchuk R.M., Uzunian M.D. Sposib elektroeroziinoho almaznoho shlifuvannia zi zminnoiu poliarnistiu elektrodiv, Patent UA, no. 131894, 2019. 2. Montes, J., Cuevas, F., Reina, F. Modelling and Simulation of the Electrical Resistance Sintering Process of Iron Powders // Met. Mater. Int. 26, pp. 1045-1059 (2020). 3. D’Urso, G., Maccarini, G., Ravasio, C. Influence of electrode material in micro-EDM drilling of stainless steel and tungsten carbide // Int J. Adv. Manuf. Technol. 85, pp. 2013-2025 (2016). 4. Giridharan, A., Samuel, G. Investigation into erosion rate of AISI 4340 steel during wire electrical discharge turning process // Machining Science and Technology, pp. 287-298, (2018). 5. R.Andreani, G.Haeser, J.M.Martinez // On sequential optimality conditions for smooth constrained optimization, Optimization 60 (2011), pp. 627-641.

\title{
Роман Стрельчук, Харків, Україна
}

\section{МОДЕЛЮВАННЯ ШОРСТКОСТІ ПОВЕРХНІ ПРИ ЕЛЕКТРОЕРОЗІЙНОМУ ШЛІФУВАННІ ЗІ ЗМІННОЮ ПОЛЯРНІСТЮ ЕЛЕКТРОДІВ}

\begin{abstract}
Анотація. Електроерозійне алмазне шліфування зі змінною полярністю електродів дозволяє обробляти важкооброблювані матеріали. Прочес формування обробленої поверхні залежить, не тільки від електричних режимів обробки, а ще й від матеріалу заготовки, від робочої рідини $i$ m.n. Ці параметри не пов'язані, отже, кожен з них дає свій вплив на хід процесу. Тому дослідження закономірностей зміни шорсткості в залежності від електричних режимів обробки виконувалося з використанням імовірнісно-статистичного моделювання. У статті проведено ймовірносно-статистичне моделювання шорсткості поверхні в прочесі електроерозіонного шлліфуванія зі змінною полярністю електродів. Встановлено взаємозв'язок між електричними режимами обробки і показниками якості обробленої поверхні. Отримано імовірнісно-статистичну модель шорсткості поверхні деталі, щзо формується при шліфуванні, яка встановлюе взаємозв'язок між висотними параметрами поверхні та електричними режимами обробки. Розроблена модель, дозволяє розрахувати висотні параметри шорсткості деталі в залежності від електричних режимів иліфування. Висота мікронерівностей визначається тими ж умовами обробки, щчо і глибина ерозійних лунок. Отримання низькоі шорсткості можливо при зниженні електричних режсимів обробки. Використання розробленого алгоритму розрахунку супроводжується великою кількістю обчислень $і$ застосуванням досить складних математичних проиедур: ріменням рівнянь чисельними методами, генерачією випадкових чисел та ін. Дані обчислення доиільно проводити в програмних пакетах. У з6'язку з иим виникає необхідність розробки алгоритмів реалізації створеної математичної моделі в програмних пакетах: моделювання шорсткості оброблюваної поверхні; визначення положення вершини ерозійної лунки, щя розглядається в площині формування поперечного мікропрофілю деталі при різних електричних режимах шліфування; розрахунок математичного очікування глибини ерозійної лунки.
\end{abstract}

Ключові слова: просторове положення ерозійних лунок; статистичні розміри; параметри шорсткості; електричні режими. 